\title{
Rediscovery of the Yesso scallop pathogen Perkinsus qugwadi in Canada, and development of PCR tests
}

\author{
Naoki Itoh ${ }^{1, *}$, Gary R. Meyer ${ }^{2}$, Amy Tabata ${ }^{2}$, Geoff Lowe $^{2}$, Cathryn L. Abbott $^{2}$, \\ Stewart C. Johnson ${ }^{2}$ \\ ${ }^{1}$ Graduate School of Agricultural Science, Tohoku University, 1-1 Tsutsumidori Amamiya-machi, Aoba-ku, Sendai 981-8555, \\ Miyagi, Japan \\ ${ }^{2}$ Pacific Biological Station, Department of Fisheries and Oceans, 3190 Hammond Bay Road, Nanaimo, \\ British Columbia V9T 6N7, Canada
}

\begin{abstract}
Perkinsus qugwadi, a pathogenic protozoan parasite of Yesso scallops Patinopecten yessoensis, is found only in cultured populations in British Columbia, Canada. This pathogen was first identified in 1988 and caused significant mortalities at some locations during the early 1990s. Prevalence of infection decreased dramatically following 1995, and the disease was last reported in 1997, leading to speculation that the Yesso scallop stocks in Canada had developed resistance to the disease, or that $P$. qugwadi had disappeared. However, the present study revealed that infection with $P$. qugwadi and associated mortality is still occurring in scallops from at least one location in British Columbia. One of the PCR tests developed for P. qugwadi detected the parasite in a $10^{5}$-fold dilution of DNA extracted from a heavily infected sample and detected $52 \%$ more positive scallops than histology; however, the assay also cross-reacted with $P$. honshuensis and P. olseni. The other PCR test was less sensitive and detected $34 \%$ more positives, but did not react to any of the other Perkinsus species tested, suggesting that these PCR tests are powerful tools for screening for the presence of $P$. qugwadi. Phylogenetic analysis of $1796 \mathrm{bp}$ of SSU rRNA gene sequence clearly indicated that $P$. qugwadi is positioned basally to other Perkinsus species.
\end{abstract}

KEY WORDS: Bivalves · Parasite disease · Perkinsus · Phylogeny · Diagnosis · Molecular detection

\section{INTRODUCTION}

The Yesso scallop Patinopecten (= Mizuhopecten) yessoensis occurs naturally in waters off northern Japan, the Russian Federation Far East, and the Korean Peninsula. Due to declining wild harvests, high market value, and high market demand, this species is widely cultured in China, Japan, Korea, and the Russian Federation. Annual production from these regions in 2007 was more than $2 \times 10^{6} \mathrm{t}$ (FAO 2009). There is also a small Yesso scallop industry in British Columbia, Canada, and this industry is based on hatchery culture of seed from broodstock that was originally introduced from Japan in 1983. This introduction strictly followed the International Council for Exploration of the Sea (ICES) Code of Practice on the Introductions and Transfers of Marine Organisms 1994 (ICES 1995). Following import into British Columbia, broodstock were held in strict quarantine, the resulting seed screened for disease by histology prior to out-planting, and finally all of the initial broodstock animals that had been introduced were destroyed. Although successful spawning and hatchery production of juveniles was achieved following 
this introduction, several diseases were identified during subsequent grow-out trials (Bower et al. 1992). Of particular concern was a protozoan parasite of unknown taxonomic affiliations referred to as scallop protozoan X (SPX), which was later described based on morphology as Perkinsus qugwadi (Blackbourn et al. 1998). Between 1988 and 1995, P. qugwadi caused significant disease at some locations, with mortality rates of up to $98 \%$ in juveniles $(<5 \mathrm{~cm}$ in shell height, $<1 \mathrm{yr}$ old) and up to $60 \%$ in adults (about $9 \mathrm{~cm}$ in shell height, 2 yr old) (Bower et al. 1998).

Perkinsus qugwadi is in the same genus as 2 other important bivalve pathogens, $P$. marinus and $P$. olseni. However, when compared to other Perkinsus species, relatively little information is available for P. qugwadi, mainly because it has not been cultured or maintained in vitro (Bower et al. 1992, Blackbourn et al. 1998). Prior to this study, P. qugwadi had not been reported in Canada since 1997 (G. Meyer unpubl.), and there has been no active surveillance or additional research on this parasite since that time, as it was no longer considered problematic by the scallop aquaculture industry.

To date, Perkinsus qugwadi has not been reported outside of British Columbia, raising the possibility that it is native to this region and that there may be other hosts for this parasite that served as reservoirs for the disease outbreaks seen in the 1980s and 1990s. The goal of this study was to re-examine areas previously known to be endemic for P. qugwadi for the presence of the parasite in Yesso scallops and other species of bivalve mollusks. To this end, we developed 2 PCR tests for detection of P. qugwadi which were used along with histology for screening. Additionally, the small subunit (SSU) ribosomal RNA gene of $P$. qugwadi was sequenced and used for phylogenetic analysis to evaluate whether molecular data support its taxonomic classification in the genus Perkinsus.

\section{MATERIALS AND METHODS}

\section{Scallop collection, tissue sampling, histology, and DNA extractions}

In October 2011, 100 juvenile Patinopecten yessoensis (mean \pm SD shell height: $29.5 \pm 4.6 \mathrm{~mm}$ ) were collected from a suspended culture site in Kanish Bay, Quadra Island, British Colombia, Canada, where a high prevalence of Perkinsus qugwadi had previously been reported (Bower et al. 1998). The left valve from each scallop was removed, and an initial examination for tissue lesions was made using a dissecting microscope. Following removal of the right valve, small portions of the gills, gonads, and digestive gland of each individual were excised and preserved in $95 \%$ ethanol for subsequent DNA extraction. The remaining tissues were fixed in Davidson's solution (Shaw \& Battle 1957), and then further dissected by cutting a 2 to $3 \mathrm{~mm}$ thick cross section through the digestive gland, gonad, gill, and mantle. Tissue samples were processed using routine histological techniques, and deparaffinized $5 \mu \mathrm{m}$ thick tissue sections were stained with Harris's modified hematoxylin and eosin. Histology slides were examined using light microscopy, and the infection status for each specimen was assessed according to the modified categories shown in Table 1 (Bower et al. 1999).

DNA was extracted from a sample containing gill, mantle, and digestive gland tissue for each scallop using a DNeasy Mini Kit (Qiagen) following the manufacturer's instructions. Individual DNA samples were stored at $4^{\circ} \mathrm{C}$ if analysis was to occur within the week or at $-20^{\circ} \mathrm{C}$ if analysis occurred at a later date.

Table 1. Perkinsus qugwadi infecting Patinopecten yessoensis. Categories for the intensity of infection in scallops by histological examination at 200 to $400 \times$ magnification

\begin{tabular}{ll} 
Category & Description \\
\hline $\begin{array}{l}\text { Negative } \\
\text { Light }\end{array}$ & $\begin{array}{l}\text { No parasite detected in the entire histological section by scanning at } 100 \text { to } 400 \times \text { magnification. } \\
\text { Fewer than } 10 \text { parasites detected. Typically observed in association with few small focal areas of } \\
\text { homocyte infiltration. Most of the tissue is free of infection. }\end{array}$ \\
& $\begin{array}{l}10 \text { to } 200 \text { parasites detected. Typically observed in association with larger and multifocal areas of } \\
\text { hemocyte infiltration. }\end{array}$ \\
Heavy & $\begin{array}{l}200 \text { to several hundred parasites detected. Infections are typically associated with large multifocal or } \\
\text { Coalescing areas of hemocyte infiltration but can also be diffuse/systemic. } \\
\text { Very heavy }\end{array}$ \\
& $\begin{array}{l}\text { Pathogen cells too numerous to count. Infection is systemic, and often the digestive gland and gonad } \\
\text { contain more parasite cells than host tissue. }\end{array}$
\end{tabular}




\section{Development of PCR tests for Perkinsus qugwadi}

The universal Perkinsus spp. PCR primers (ITS85/ ITS750) developed by Casas et al. (2002a) failed to amplify the targeted product from $P$. qugwadi (data not shown). Accordingly, we used rDNA ITS1 to ITS2 regions of $P$. qugwadi (GenBank accession no. AF151528) to design PCR primers, as these areas are known to be highly variable among the Perkinsus species (Casas et al. 2002a, b, Dungan et al. 2002).

Primers for PCR-1 were PqugF9 and PqugR9b (Table 2) based on the ITS2 region of Perkinsus qugwadi, and the final volume of each PCR reaction was $20 \mu$ and contained $1 \times$ PCR buffer, $1.5 \mathrm{mM} \mathrm{MgCl}_{2}$,

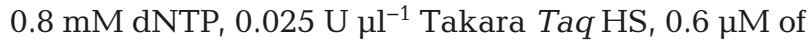
each primer, and $1 \mu \mathrm{l}$ of extracted template DNA. The thermocycler program consisted of an initial denaturation at $94^{\circ} \mathrm{C}$ for $3 \mathrm{~min}$, followed by 40 cycles of $94^{\circ} \mathrm{C}$ for $30 \mathrm{~s}, 53^{\circ} \mathrm{C}$ for $30 \mathrm{~s}, 72^{\circ} \mathrm{C}$ for $30 \mathrm{~s}$, and a final extension at $72^{\circ} \mathrm{C}$ for $10 \mathrm{~min}$. The expected PCR product from $P$. qugwadi DNA in this assay was $143 \mathrm{bp}$.

Primers for PCR-2 were PqugF7TC in the ITS1 region and PQ3R in the ITS2 region (Table 2). The final volume of PCR reactions was $20 \mu \mathrm{l}$ and contained 1× Platinum Taq Buffer (Invitrogen), $1.5 \mathrm{mM}$ $\mathrm{MgCl}_{2}, 0.2 \mathrm{mM} \mathrm{dNTP}, 0.3 \mathrm{M}$ of each primer, $0.02 \mathrm{U}$ $\mathrm{\mu l}^{-1}$ Platinum Taq (Invitrogen), and $1 \mu \mathrm{l}$ of extracted template DNA. The same thermocycler program was used as above except the annealing temperature was $54^{\circ} \mathrm{C}$. The expected PCR product from Perkinsus qugwadi DNA in this assay was $281 \mathrm{bp}$.

The products for PCR-1 and PCR-2 were visualized on 2.0 and $1.5 \%$ agarose gels, respectively, stained with SYBR Safe (Invitrogen). PCR products were extracted using a QIAquick Gel extraction Kit (Qiagen), and directly sequenced with PCR primers by an external sequencing facility (Macrogen Japan).
Specificity of both PCR tests was assessed using DNA samples of all 7 described Perkinsus species. Sources of DNA were isolates of $P$. olseni (ATCC no. PRA-181), P. chesapeaki (ATCC no. PRA-65), P. honshuensis (ATCC no. PRA-177), and P. mediterraneus (Pmed-G2) (Casas et al. 2008), as well as tissues of Crassostrea virginica infected with $P$. marinus and $C$. ariakensis infected with $P$. beihaiensis. To confirm the presence of $P$. marinus and $P$. beihaiensis in infected tissues, we conducted PCR using the universal primers for Perkinsus spp., ITS85/ITS750 (Casas et al. 2002a) and directly sequenced the products. The sequences of the products from $C$. virginica and $C$. ariakensis were identical to rRNA sequences of $P$. marinus (GQ861511, AY295199, and AY295198) and P. beihaiensis (JN054741), respectively. The positive control sample was DNA extracted from a scallop that was categorized as having a very heavy infection with $P$. qugwadi by histological examination. Sensitivity of both PCR tests was evaluated using serial dilutions of the positive control sample with DNA from an uninfected scallop, as well as by comparing the PCR test results with those of histology for all 100 juvenile scallops.

\section{Examination of native bivalve species for infection with Perkinsus qugwadi}

Nine bivalve species native to British Columbia were collected from Kanish Bay and Granite Bay and tested for infection with Perkinsus qugwadi (Table 3). Specimens were collected as close as possible to juvenile scallops; however, these distances ranged from $<1 \mathrm{~m}$ to about $1500 \mathrm{~m}$, depending on species abundance and habitat suitability. Tissue sampling and DNA extraction procedures

Table 2. PCR primers used in this study

\begin{tabular}{|llll|}
\hline Usage & Primers & Direction & Sequence \\
\hline PCR-1 & PqugF9 & Forward & 5'-TCC CGC TTG ATA ACT AAC TCG-3' $^{\prime}$ \\
PCR-2 & PqguR9b & Reverse & $5^{\prime}$-GTG CTG AAG GAG TAC TGT GC-3' \\
& PqguF7TC & Forward & $5^{\prime}$-CCA CTC TGG TAG TCT TGT CTT C-3' \\
Gene identification & PQ3R & Reverse & $5^{\prime}$-AGA ATG GCG ACG CTG ATG AA-3' \\
& Pm18S-1098F & Forward & $5^{\prime}$-AGG AAT TGA CGG AAG GG CA-3 \\
& PqITS-22R & Reverse & $5^{\prime}$ 'CGC AGT TTA AAT GAA TCG GT-3' \\
& Puniv18S-F & Forward & $5^{\prime}$-CCT GGT TGA TCC TGC CAG T-3' \\
& Pq18S-1198R & Reverse & $5^{\prime}$ '-TCC TTC CCA TGT CTG GAC CT-3' \\
& Pm18S-582F & Forward & $5^{\prime}$-ACG AGT ATC AAT TGG AGG GC-3' \\
& Pm18S-710R & Reverse & $5^{\prime}$ '-GGC AGA AAT CCA ACT ACG AGC-3' \\
\hline
\end{tabular}


Table 3. Native bivalve species examined as potential hosts for infection with Perkinsus qugwadi. DNA samples from multiple individuals were pooled and examined by PCR-1

\begin{tabular}{|lrcc|}
\hline Species & Number & $\begin{array}{c}\text { Collection } \\
\text { site }\end{array}$ & $\begin{array}{c}\text { Ind. } \\
\text { pool }^{-1}\end{array}$ \\
\hline Mussels (Mytilus sp.) & 30 & Kanish Bay & 6 \\
Rock oyster Pododesmus macrochisma & 32 & Kanish Bay & 4 \\
Spiny scallop Chlamys hastata & 9 & Kanish Bay & 3 \\
Nestling saxicata clams (Hiatella sp.) & 9 & Kanish Bay & 3 \\
Bent-nose clam Macoma nasuta & 30 & Granite Bay & 6 \\
Soft-shell clam Mya arenaria & 2 & Granite Bay & 1 \\
Pointed macoma Macoma inquinata & 12 & Granite Bay & 4 \\
Native little neck clam Protothaca staminea & 30 & Granite Bay & 6 \\
Basket cockle Clinocardium nuttalli & 30 & Granite Bay & 6 \\
\hline
\end{tabular}

were the same as those used for juvenile scallops, except that following extraction, DNA from 3 to 8 individuals was pooled (Table 3 ), and $0.5 \mu$ l of the pooled DNA was added to a $10 \mu \mathrm{l}$ PCR reaction mixture. For this examination, PCR-1 was used as described above, but histological examination was only conducted on specimens that tested positive by PCR.

\section{Identification of Perkinsus qugwadi SSU rRNA gene and phylogenetic analysis}

To examine the phylogenetic position of Perkinsus qugwadi, a $1796 \mathrm{bp}$ region of the SSU rRNA gene was amplified and sequenced. Template DNA was extracted from a heavily infected scallop (as identified by histology) using a DNeasy Mini Kit (Qiagen) following the manufacturer's instructions. The SSU rRNA gene of $P$. qugwadi was amplified as follows using a combination of universal and specific primers. The final volume of all PCR reactions was $20 \mu \mathrm{l}$ and contained 1× Titanium Taq Buffer (Clontech), $1.5 \mathrm{mM} \mathrm{MgCl}_{2}, 0.2 \mathrm{mM}$ dNTP, $0.2 \mu \mathrm{M}$ of each primer, $0.05 \mathrm{U} \mathrm{\mu l}^{-1}$ Titanium Taq (Clontech), and $2 \mu \mathrm{l}$ of extracted template DNA. Using primer Pm18S-1098F (Table 2) designed in a conserved region of the SSU rRNA gene of eukaryotes, and primer PqITS-22R (Table 2) designed in the ITS1 region of $P$. qugwadi (GenBank accession no. AF151528), an initial PCR reaction was performed. The thermocycler program consisted of an initial denaturation at $94^{\circ} \mathrm{C}$ for $5 \mathrm{~min}$, followed by 30 cycles of $94^{\circ} \mathrm{C}$ for $30 \mathrm{~s}, 54^{\circ} \mathrm{C}$ for $30 \mathrm{~s}$, and extension at $72^{\circ} \mathrm{C}$ for $45 \mathrm{~s}$, and final extension at $72^{\circ} \mathrm{C}$ for $7 \mathrm{~min}$. PCR products were sequenced using both PCR primers in a $10 \mu \mathrm{l}$ reaction containing 1.6 pmol primer, $1 \mu \mathrm{l}$ of BigDye Termina- tor v. 3.1 (Applied Biosystems), $2 \mu \mathrm{l}$ of $5 \times$ Sequencing Buffer (Applied Biosystems), $5.5 \mu \mathrm{l}$ of molecular-grade water, and $1 \mu \mathrm{l}$ of PCR product, previously purified with ExoSAP-IT (Affymetrix). Sequencing products were run on an ABI 3130xl Genetic Analyzer (Applied Biosystems), and data were viewed and edited using Sequencher v. 5.0 (Gene Codes).

The upstream region of SSU rRNA gene was amplified using the primer Pq18S-1198R (Table 2) designed from the initial sequences that we obtained, and Puniv18S-F (Table 2) designed at the $5^{\prime}$ end of SSU rRNA gene from Perkinsus olseni (GenBank accession no. AF509333), $P$. andrewsi (= P. chesapeaki) (AY30 5326), and $P$. marinus (AF497479). The thermocycler program consisted of an initial denaturation at $94^{\circ} \mathrm{C}$ for $5 \mathrm{~min}$, followed by 35 cycles of $94^{\circ} \mathrm{C}$ for $30 \mathrm{~s}$, $57^{\circ} \mathrm{C}$ for $30 \mathrm{~s}, 72^{\circ} \mathrm{C}$ for $90 \mathrm{~s}$, and final extension at $72^{\circ} \mathrm{C}$ for $7 \mathrm{~min}$. PCR products of the appropriate size (1200 bp) were purified from a 1.5\% agarose gel using a QIAquick DNA Gel Extraction Kit (Qiagen). The resulting DNA was sent to Macrogen Japan for direct sequencing with the PCR primers and Pm18S-582F and Pm18S-710R (Table 2) which were designed from SSU rRNA gene sequences of Perkinsus spp. as described above. A contiguous sequence was assembled manually by ClustalW, and homology searches were conducted using nucleotide BLAST (http://blast.ncbi.nlm.nih.gov/ Blast.cgi). The SSU rRNA gene sequence data were aligned with selected relevant species using ClustalW and analyzed by maximum likelihood with a general time reversible model and the neighbor-joining method with Kimura's 2-parameter model using MEGA 5 (Tamura et al. 2011). Organisms used for phylogenetic analysis were 5 Perkinsus spp., viz. P. marinus (AF497479), P. olseni (AF509333), P. mediterraneus (AY487831), P. andrewsi ( $=P$. chesapeaki; AY305326), and P. qugwadi (this work); 2 dinoflagellates, Prorocentrum micans (EU780638) and Heterocapsa triquetra (AF022198); 2 apicomplexans, Eimeria nieschulzi (U40263) and Cryptosporidium parvum (AF0934 94); and 2 ciliates, Paramecium caudatum (AF2176 55) and Oxytricha laceolata (AM412773). In total, $1782 \mathrm{bp}$ of alignment were used for analysis, and 158 gaps in the alignment were treated as missing data. Bootstrap values were calculated with 1000 replicates. 


\section{RESULTS}

\section{Field surveillance and histology}

Gross examination revealed that 17 scallops showed signs characteristic of infection with Perkinsus qugwadi. These signs included the presence of distended opaque gonads and/or white pustules in the digestive gland. Histological examination confirmed that 16 of these 17 specimens were indeed infected with $P$. qugwadi. In total, $P$. qugwadi was detected by histology in 44 of 100 juvenile scallops examined. Intensity of infections was categorized and enumerated as follows: light $(\mathrm{n}=9)$, moderate $(\mathrm{n}=11)$, heavy $(\mathrm{n}=20)$, very heavy $(\mathrm{n}=4)$, and negative with no parasites observed $(\mathrm{n}=56)$.

In histological sections, Perkinsus qugwadi was commonly observed in the gonad, digestive gland (Fig. 1A), mantle, and gill tissues (Fig. 1B), regardless of infection intensity. Focal lesions consisting of parasites and hemocyte infiltration (Fig. 1A) were frequently observed in specimens with light to moderate intensity infections. All developmental stages described in a previous report (Blackbourn et al. 1998), such as trophozoites (Fig. 1C,D), tomonts (Fig. 1D), and zoosporangia (Fig. 1E), were present. Zoospores were also observed, but only in very heavily infected individuals, which typically had an overwhelming number of parasite cells that replaced most of the connective tissue (Fig. 1F).

\section{Development of diagnostic PCR tests and comparison with histology}

PCR-1 did not prove to be species specific, as weak cross-reactions were observed with Perkinsus honshuensis and P. olseni (Fig. 2A). In addition, this primer set also produced large amplicons of approximately 1000 bp with $P$. chesapeaki and negative control scallop DNA. Although this assay was found to be lacking with respect to species specificity, it was found to be highly sensitive, allowing for detection of $P$. qugwadi DNA in a positive sample that had been diluted 100000 -fold with host DNA from uninfected individuals (Fig. 2B). All 44 individuals that tested positive for $P$. qugwadi by histological examination also tested positive using this PCR test. An additional 23 specimens tested positive by this PCR but were negative by histology. Thirty-three individuals tested negative by both histology and PCR-1 (Table 4A).

The PCR-2 test proved to be highly specific for Perkinsus qugwadi and did not cross-react with any
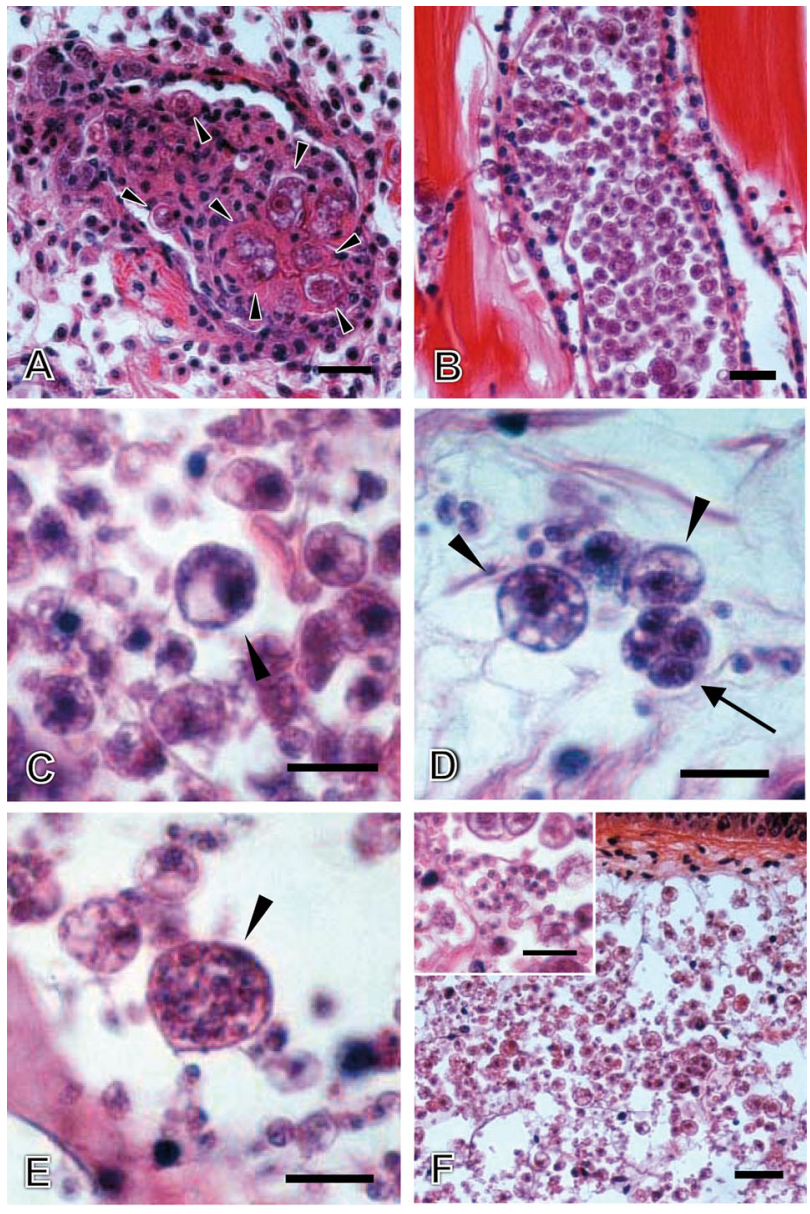

Fig 1. Patinopecten yessoensis infected with Perkinsus qugwadi. Histological sections (stained with hemotoxylin and eosin) of juvenile scallops. (A) Intensive hemocyte infiltration surrounding $P$. qugwadi trophozoites (arrowheads) in the connective tissue of the digestive gland. (B) Hemal space of the gill filament filled with $P$. qugwadi cells. (C) Trophozoite with a prominent cytoplasmic vacuole, known as 'signet ring,' in the connective tissue of the digestive gland. (D) Trophozoites (arrowheads) and an immature tomont (arrow) containing 4 developing trophozoites in the connective tissue of the digestive gland. (E) Zoosporangium (arrowhead) containing zoospores in the connective tissue of the digestive gland. (F) Very heavy infection showing the connective tissue of the digestive gland almost completely replaced with parasite cells including zoospores (inset).

Scale bars $=(A, B, F) 20 \mu \mathrm{m},(C, D, E$ inset in F $) 10 \mu \mathrm{m}$

of the other Perkinsus species (Fig. 2A). Although a faint band was observed from $P$. chesapeaki, the product size was larger than $300 \mathrm{bp}$ and distinguishable from the $281 \mathrm{bp}$ PCR product of P. qugwadi. The sensitivity of PCR-2 was lower than PCR-1; however, it still enabled detection of $P$. qugwadi DNA in a positive sample diluted 10000 -fold with uninfected host DNA (Fig. 2B). Forty-one individuals that tested pos- 
A

M Pbei Pche Phon Pmar Pmed Pols Pqug -ve NTC M
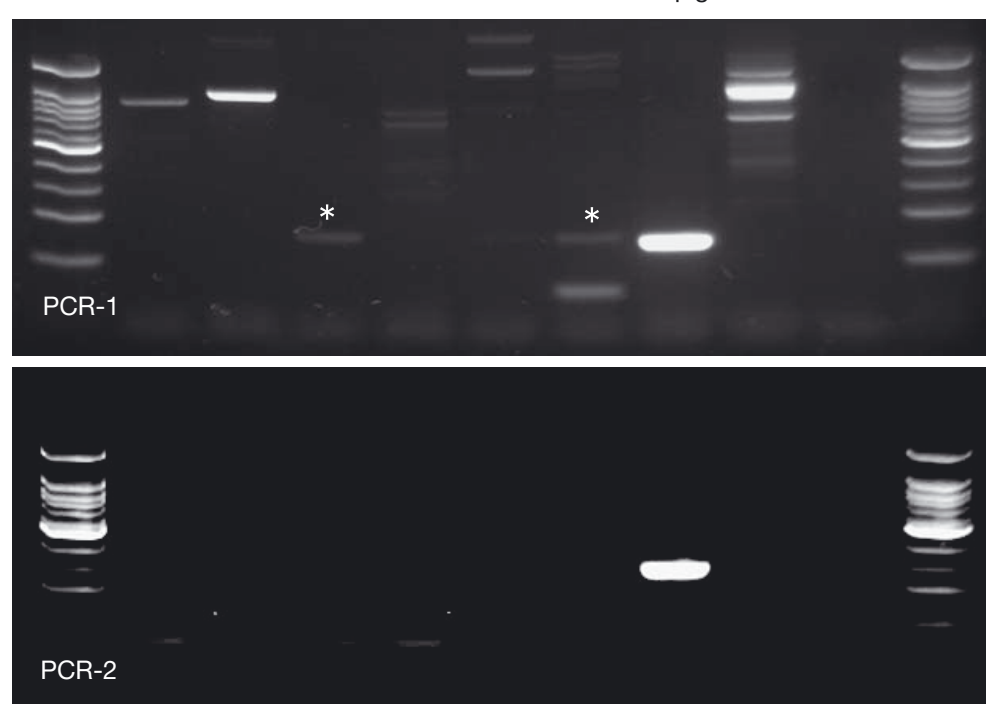

B

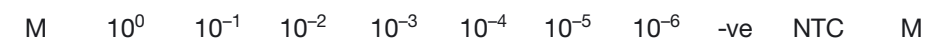
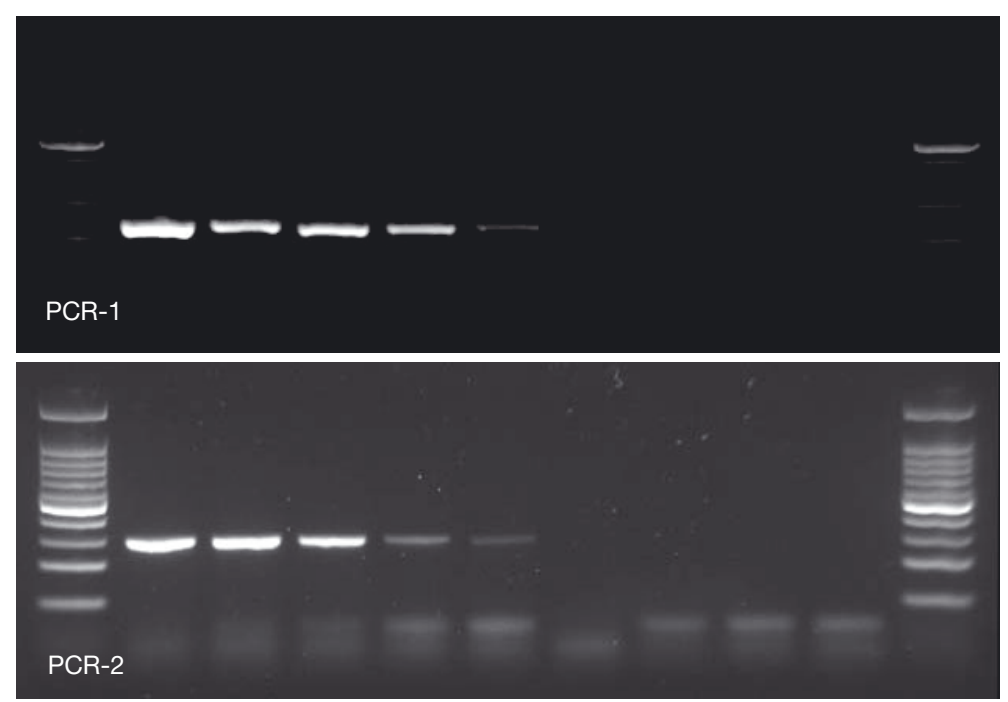

Fig. 2. Perkinsus spp. Agarose gel electrophoresis showing PCR-1 with primer set PqugF9/PqugR9b (upper) and PCR-2 with primer set PqugF7TC/PQ3R (lower). (A) Specificity testing of the PCR tests using DNA from Perkinsus spp. Pbei: P. beihaiensis; Pche: P. chesapeaki; Phon: P. honshuensis; Pmar: P. marinus; Pmed: P. mediterraneus; Pols: P. olseni; Pqug: $P$. qugwadi; -ve: uninfected healthy scallop; NTC: non-template control; M: 100 bp DNA ladder (Promega). Note that non-specific amplification products (asterisks) were produced from $P$. honshuensis and $P$. olseni. (B) Sensitivity testing of the PCR tests using $P$. qugwadi DNA extracted from a very heavily infected individual which was serially 10 -fold diluted with DNA from a non-infected healthy scallop

itive by histology were also positive by this PCR assay, but 3 individuals positive by histology were negative by this assay. An additional 18 specimens were positive by PCR, but negative by histology, and
38 individuals were negative by both PCR and histology (Table 4B).

Comparison of the 2 PCR tests shows that 52 individuals were positive by both PCR tests. Fifteen specimens were positive by PCR-1, but negative by PCR-2, while 7 individuals were negative by PCR-1, but positive by PCR-2. The reason for the discrepancy between these 2 PCR assays remains unknown, but it is speculated that differences in the structure of the amplified DNA region or DNA polymerase may affect the sensitivity. Twentysix individuals were negative by both PCR tests (Table 4C).

\section{Detection of Perkinsus qugwadi in native bivalve species}

Since no other Perkinsus species are known to occur in British Columbia, the highly sensitive PCR-1 was used for this portion of the study. P. qugwadi was initially detected by PCR in some of the pooled samples of DNA from the native bivalve species. Additional PCR tests were conducted on individual DNA samples which yielded positive results for 4 mussels (Mytilus spp.), 2 rock oysters Pododesmus macrochisma, and 1 native little neck clam Protothaca staminea. However, a subsequent histological examination did not detect $P$. qugwadi in any of these individuals.

\section{Identification of SSU rRNA gene sequence and phylogenetic analysis}

A 1796 bp sequence of the Perkinsus qugwadi SSU and ITS1 rRNA gene was obtained and deposited in GenBank under accession number AB716689. A nucleotide BLAST search revealed that this sequence was most similar to the SSU rRNA gene of $P$. olseni, $P$. mediterraneus, and $P$. chesapeaki, having $96 \%$ identities to each. Both maximum likelihood (Fig. 3A) and neighbor-joining (Fig. 3B) trees showed that the Perkinsus species were placed as a sister clade of the dinoflagellates, and that $P$. qugwadi was at the base of this clade. 
Table 4. Comparisons among PCR tests and histology for diagnoses of Perkinsus qugwadi. (A) Comparison between PCR-1 and histology. (B) Comparison between PCR-2 and histology. (C) Comparison between PCR-1 and PCR-2

\begin{tabular}{|c|c|c|c|c|}
\hline \multirow[t]{2}{*}{ (A) } & & \multirow[b]{2}{*}{ Positive } & \multirow{2}{*}{$\begin{array}{l}\text { Histology } \\
\text { Negative }\end{array}$} & \multirow[b]{2}{*}{ Total } \\
\hline & & & & \\
\hline \multirow[t]{2}{*}{ PCR-1 } & Positive & 44 & 23 & 67 \\
\hline & Negative & 0 & 33 & 33 \\
\hline \multicolumn{2}{|l|}{ Total } & 44 & 56 & 100 \\
\hline \multirow[t]{2}{*}{ (B) } & & & Histology & 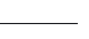 \\
\hline & & Positive & Negative & Total \\
\hline \multirow[t]{2}{*}{ PCR-2 } & Positive & 41 & 18 & 59 \\
\hline & Negative & 3 & 38 & 41 \\
\hline Total & & 44 & 56 & 100 \\
\hline \multirow[t]{2}{*}{ (C) } & & & - PCR-1 & 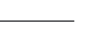 \\
\hline & & Positive & Negative & Total \\
\hline \multirow[t]{2}{*}{ PCR-2 } & Positive & 52 & 7 & 59 \\
\hline & Negative & 15 & 26 & 41 \\
\hline Total & & 67 & 33 & 100 \\
\hline
\end{tabular}

\section{DISCUSSION}

Prior to this study, the last reported occurrence of Perkinsus qugwadi in Yesso scallops cultured along the west coast of Canada occurred in 1997. Bower et al. (1999) attributed the disappearance of this parasite from British Columbia to the development of resistance within stocks of Yesso scallops that had survived earlier infection. In our study, juvenile scallops with characteristic gross signs of infection with $P$. qugwadi were collected from the previous endemic area. These infections were confirmed by histological examination. As the morphology of trophozoites, tomonts, and zoospores were identical to those described for $P$. qugwadi (Bower et al. 1992, 1998, Blackbourn et al. 1998), we concluded that $P$. qugwadi still exists in British Columbia. In addition, at the time of sampling, mortality among juvenile scallops from the study area was estimated to be $20 \%$; it now seems likely that this is at least partially attributable to infection with $P$. qugwadi, suggesting that this pathogen is still causing problems for scallop aquaculture in British Columbia.
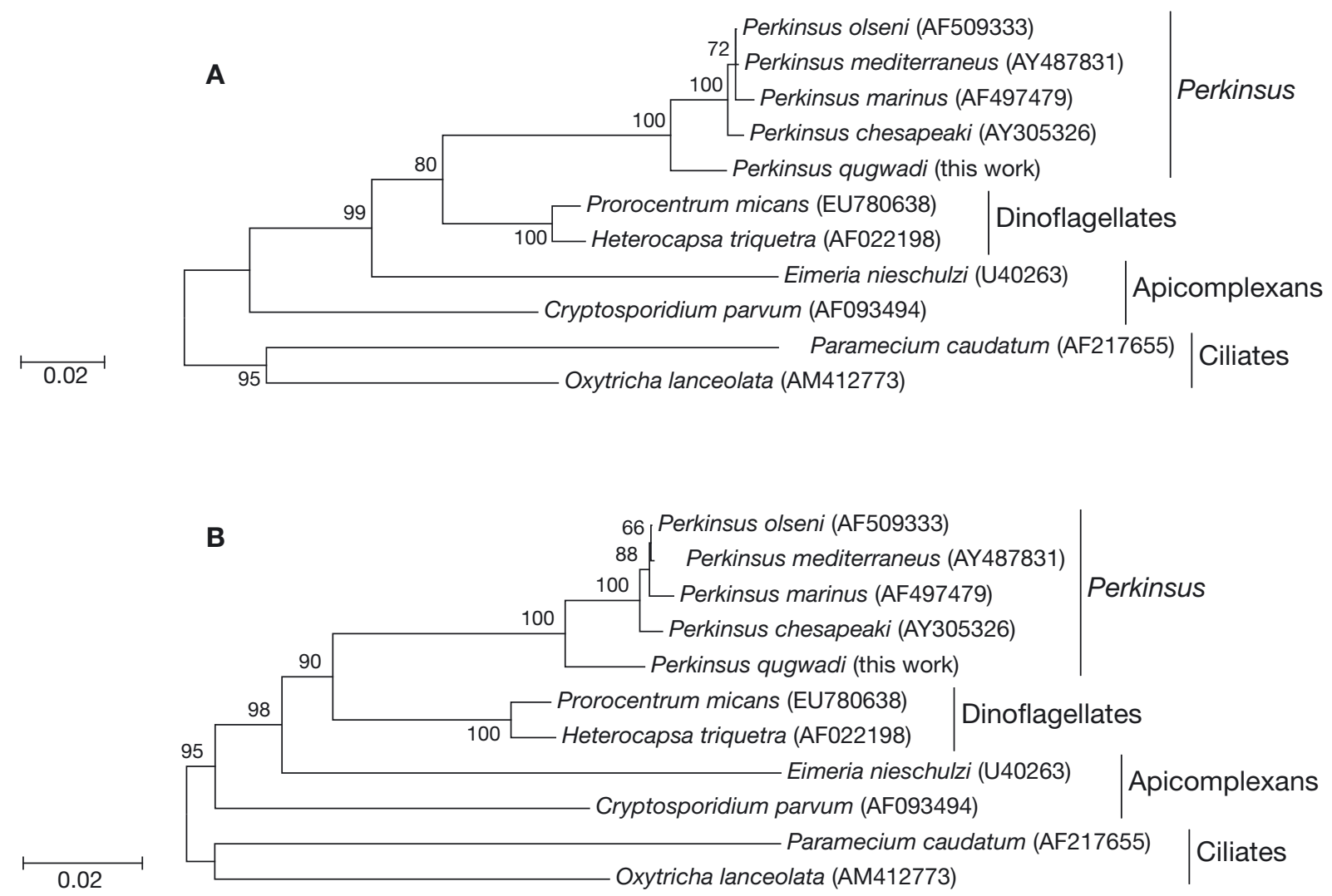

Fig. 3. Inferred phylogenetical relationships of selected Perkinsus spp., dinoflagellates, apicomplexans, and ciliates by (A) maximum likelihood and (B) neighbor joining based on SSU rRNA gene sequences. Bootstrap values were calculated with 1000 replicates, and values $>50 \%$ are shown at the nodes 
We developed 2 PCR tests for Perkinsus qugwadi that provide a rapid and sensitive detection method for disease surveillance and research purposes. PCR1 using primer set PqugF9 and PqugR9b was not species specific, as it cross-reacted with the DNA of $P$. honshuensis and P. olseni; however, it was highly sensitive and had detection levels equal to a $100000-$ fold dilution of $P$. qugwadi in host DNA. All specimens that tested positive by histology also tested positive by this PCR test. In addition, the PCR test detected parasite DNA in 52\% more specimens than histology, indicating the usefulness of this method as a screening test for P. qugwadi. Although PCR-1 was not species specific, it is still considered to be a useful screening test for $P$. qugwadi, particularly in locations such as British Columbia, where the other species of Perkinsus do not occur.

PCR-2 using primer set PqugF7TC and PQ3R had high specificity to Perkinsus qugwadi; however, the sensitivity was lower when compared to PCR-1. Although 3 individuals that tested positive by histology were not detected by PCR-2, this PCR test detected parasite DNA in $34 \%$ more specimens than histology. Therefore, PCR-2 is still considered very useful for $P$. qugwadi screening, particularly in locations such as Japan where $P$. honshuensis and P. olseni are endemic.

As with any PCR-based diagnostic test, caution should always be used when interpreting results, especially from bivalve mollusks (Burreson 2008). There are several possible reasons why some specimens tested positive by PCR but not by histology, including: (1) the presence of extremely light or cryptic infections, (2) the possibility that there are as yet unknown developmental stages of this parasite, and (3) the possibility that zoospore or other pathogen cell types may be adhered to gills, or inside the gut and not represent a 'true' infection. Future research including development of an in situ hybridization assay would be needed to further investigate the reason for discrepancies between these diagnostic methods. We recommend that a combination of both PCR and histology should be used, especially for surveillance and diagnosis of Perkinsus qugwadi from new areas or hosts. This recommendation follows that suggested by Burreson (2008) for other protistan infections of bivalves.

Introduction of the Yesso scallop into Canada was conducted according to the ICES Code of Practice on the Introductions and Transfers of Marine Organisms 1994 (ICES 1995), and broodstock from Japan were destroyed after the production of juveniles (Bower et al. 1998). Since Perkinsus qugwadi and its associated mortality have not been reported in Japan, it is considered that the original host species of $P$. qugwadi is likely a native species in Canada. In the present study, we detected $P$. qugwadi DNA in a total of 7 individuals from 3 native bivalve species; however, no infections could be confirmed by histological examination. Again, it is possible that the PCR test detected a free-living stage of $P$. qugwadi or that there are unknown morphological stages of $P$. qugwadi. Further testing of native bivalve species using PCR, histology, and in situ hybridization would be required to establish with certainty whether other hosts of this parasite occur in British Columbia. Such studies would be of particular value for the Pacific pink scallop Chlamys rubida, which was shown to be slightly susceptible to infection under experimental conditions (Bower et al. 1999).

Differences in the ultrastructure of some organelles, developmental stages, and diagnosis by Ray's fluid thioglycollate medium (RFTM) assays (Ray 1966) between Perkinsus qugwadi and other Perkinsus spp. have been recognized (Blackbourn et al. 1998). Also, in past phylogenetic analyses using ITS1 rRNA gene, $P$. qugwadi was consistently shown as an outgroup of the Perkinsus genera (Casas et al. 2002a,b, Dungan et al. 2002), and the phylogenetic relationship of $P$. qugwadi to other Perkinsus spp. had yet to be examined. The present study sequenced the SSU rRNA gene of $P$. qugwadi, which is often used for phylogenetic analysis in various organisms (e.g. Littlewood et al. 1999, Cavalier-Smith \& Chao 2003), and demonstrated that $P$. qugwadi can be phylogenetically placed in a basal position relative to the other Perkinsus spp., implying the importance of $P$. qugwadi in understanding the evolution of the genus Perkinsus.

Acknowledgements. We thank Island Scallop Ltd. for providing scallops and assisting with field collections. We are also grateful to the following scientists for providing DNA samples: R. Carnegie and N. Stokes from the Virginia Institute of Marine Science (for P. marinus, $P$. beihaiensis, $P$. honshuensis, and P. chesapeaki); S. Casas and J. La Peyre from Louisiana State University (for P. mediterraneus); and T. Yoshinaga from the University of Tokyo (for P. olseni). This research was supported by the Sustainable Agricultural Project, Graduate School of Agriculture Science, Tohoku University, and the Pacific Biological Station, Department of Fisheries and Oceans, Canada.

\section{LITERATURE CITED}

Blackbourn J, Bower SM, Meyer GR (1998) Perkinsus qugwadi sp. nov. (incertae sedis), a pathogenic protozoan parasite of Yesso scallops, Patinopecten yessoensis, cultured in British Columbia, Canada. Can J Zool 76: 942-953

Bower SM, Blackbourn J, Meyer GR, Nishimura DJH (1992) 
Diseases of cultured Yesso scallops (Patinopecten yessoensis) in British Columbia, Canada. Aquaculture 107: 201-210

Bower SM, Blackbourn J, Meyer GR (1998) Distribution, prevalence, and pathogenicity of the protozoan Perkinsus qugwadi in Yesso scallops, Patinopecten yessoensis, cultured in British Columbia. Can J Zool 76:954-959

Bower SM, Blackbourn J, Meyer GR, Welch DW (1999) Effect of Perkinsus qugwadi on various species and strains of scallops. Dis Aquat Org 36:143-151

Burreson EM (2008) Misuse of PCR assay for diagnosis of mollusc protistan infections. Dis Aquat Org 80:81-83

Casas SM, Villalba A, Reece KS (2002a) Study of perkinsosis in the carpet shell clam Tapes decussatus in Galicia (NW Spain). I. Identification of the aetiological agent and in vitro modulation of zoosporulation by temperature and salinity. Dis Aquat Org 50:51-65

Casas SM, La Peyre JF, Reece KS, Azevedo C, Villalba A (2002b) Continuous in vitro culture of the carpet shell clam Tapes decussatus protozoan parasite Perkinsus atlanticus. Dis Aquat Org 52:217-231

Casas SM, Reece KS, Li Y, Moss JA, Villalba A, La Peyre JF (2008) Continuous culture of Perkinsus mediterraneus, a parasite of the European flat oyster Ostrea edulis, and characterization of its morphology, propagation, and extracellular proteins in vitro. J Eukaryot Microbiol 55: $34-43$

Cavalier-Smith T, Chao EEY (2003) Phylogeny of Choano-

Editorial responsibility: Mike Hine, Fouras, France zoa, Apusonzoa, and other Protozoa and early eukaryote megaevolution. J Mol Evol 56:540-563

Dungan CF, Hamilton RM, Hudson KL, McCollough CB, Reece KS (2002) Two epizootic diseases in Chesapeake Bay commercial clams, Mya arenaria and Tagelus plebeius. Dis Aquat Org 50:67-78

FAO (Food and Agriculture Organization of the United Nations) (2009) FAO yearbook. Fishery and aquaculture statistics 2007. FAO, Rome

ICES (International Council for the Exploration of the Sea) (1995) ICES Code of Practice on the Introductions and Transfers of Marine Organisms 1994. International Council for the Exploration of the Sea, Copenhagen

Littlewood DTJ, Rohde K, Clough KA (1999) The interrelationships of all major groups of Platyhelminthes: phylogenetic evidence from morphology and molecules. Biol J Linn Soc 66:75-114

Ray SM (1966) A review of the culture method for detecting Dermocystidium marinum, with suggested modifications and precautions. Proc Natl Shellfish Assoc 54:55-69

Shaw BL, Battle HI (1957) The gross and microscopic anatomy of the digestive tract of the oyster Crassostrea virginica (Gmelin). Can J Zool 35:325-347

Tamura K, Peterson D, Peterson N, Stecher G, Nei M, Kumar S (2011) MEGA5: Molecular evolutionary genetics analysis using maximum likelihood, evolutionary distance, and maximum parsimony methods. Mol Biol Evol 28: 2731-2739

Submitted: June 28, 2012; Accepted: January 21, 2013 Proofs received from author(s): March 22, 2013 